\title{
Effects of graded levels of Curcuma longa Powder on in vivo digestibility in Guinea pigs (Cavia porcellus)
}

Gina France Tobou Djoumessi, Fernand Tendonkeng, Emile Miégoué, Clément Emalé, David Fokom Wauffo \& Jean-Luc Hornick

Gina France Tobou Djoumessi : MSc, PhD Student, Cameroonian, Animal Nutrition Laboratory, Department of Animal Production, FASA, Dschang University, Dschang, Cameroon. P.O. Box: 222. Corresponding author: ginafdjoumessi@gmail.com

Fernand Tendonkeng : BSc, PGD, MSc, PhD, Associate Professor, Cameroonian, Animal Nutrition Laboratory, Department of Animal Production, FASA, Dschang University, Dschang, Cameroon. P.O. Box: 222. E-mail: f.tendonkeng@univ-dschang.org

Emile Miégoué : PhD, Senior Lecturer, Cameroonian, Animal Nutrition Laboratory, Department of Animal Production, FASA, Dschang University, Dschang, Cameroon. P.O. Box: 222. E-mail: migoumile@yahoo.fr

Clément Emalé : MSc, PhD Student, Cameroonian, Animal Nutrition Laboratory, Department of Animal Production, FASA, Dschang University, Dschang, Cameroon. P.O. Box: 222. E-mail: jcemale@yahoo.com

David Fokom Wauffo : MSc, PhD Student, Cameroonian, Animal Nutrition Laboratory, Department of Animal Production, FASA, Dschang University, Dschang, Cameroon. P.O. Box: 222. E-mail: fokomwauffod@yahoo.fr

Jean-Luc Hornick : DMV, Ms Trop Sc, Ms Anim Prod, PhD Animal Nutrition in Tropical Countries Tropical Veterinary Institute, Department of Animal Production, Faculty of Veterinary Medicine, B43 Quartier Vallée 2 - Avenue de Cureghem, 6 B-4000 Liège - Belgium, E-mail: jlhornick@uliege.be

DOI: $10.25518 / 2295-8010.1847$

\section{Résumé :}

L'effet de l'incorporation de la poudre du Curcuma longa comme phytobiotique sur l'ingestion et la digestibilité in vivo des nutriments a été mesuré sur un total de 40 cobayes de race anglaise ayant un poids moyen de $452 \pm 75 \mathrm{~g}$. La poudre de racines de Curcuma longa a été incorporée dans l'aliment composé à des niveaux croissants $(0 ; 0,25 ; 0,5$ et $1 \%)$. Chaque ration a été granulée. Pendant l'essai de digestibilité qui a duré 17 jours (10 jours d'adaptation et 07 jours de collecte des données), chaque ration était répétée sur 10 cobayes ( 5 mâles et 5 femelles). L'inclusion de la poudre de Curcuma longa a amélioré de manière significative $(\mathrm{p}<0,05)$ l'ingestion alimentaire des cochons d'inde quel que soit le niveau d'inclusion considéré dans les rations. La digestibilité de la matière sèche de la ration contenant $0,25 \%$ de Curcuma longa a été comparable à celle de la ration $\mathrm{R}_{0} \%$ et $\mathrm{R}_{1 \%}$. En outre, la digestibilité de la cellulose brute de la ration $\mathrm{R}_{0,25 \%}$ a été comparable à celle des rations $\mathrm{R}_{0,5 \%}$ et $\mathrm{R}_{1} \%$, mais significativement plus élevée que celle des rations $\mathrm{R}_{0} \%$. L'inclusion de la poudre de Curcuma longa dans les rations a 
Effects of graded levels of Curcuma longa Powder on in vivo digestibility in ...

permis d'améliorer l'ingestion et la digestibilité de la ration chez des cochons d'inde. D'autres études doivent être réalisées afin de déterminer les causes de ces effets.

Mots-clés : Curcuma longa, Cavia porcellus, digestibilité, ingestion

\section{Abstract :}

The effect of the use of Curcuma longa powder as phytobiotic on feed intake and in vivo digestibility of nutrients was studied in 40 guinea pigs of English breed. This study was designed to evaluate the effects of incorporating graded levels of Curcuma longa powder on feed intake and in vivo digestibility in Guinea pigs. Forty (40) Guinea pigs (20 males and 20 females) of English breed, mean weight $452 \pm 75 \mathrm{~g}$ were allocated to four experimental treatments in a completely randomized design. Each treatment contains 10 Guinea pigs ( 5 males and 5 females). Three experimental rations were formulated from the basal diet $(0 \%)$ by adding $0.25,0.5$ and $1 \%$ C. longa powder corresponding to $\mathrm{R}_{0} \%, \mathrm{R}_{0.25} \%, \mathrm{R}_{0.5 \%}$ and $\mathrm{R}_{1} \%$ respectively. Digestibility test was carried out for a period of 17-days (10 days for adaptation and 7 days for data collection). The inclusion of Curcuma longa powder significantly improved $(p<0.05)$ feed intake regardless of the level of inclusion in the diets. Dry matter (DM) digestibility of the ration containing $0.25 \%$ Curcuma longa was comparable to that of the rations with 0 and $1 \%$ C. longa. The digestibility of crude fiber (CF) of Guinea pigs fed with $0.25 \%$ C. longa was comparable to those fed with 0.5 and $1 \%$. longa, but significantly higher than control ration without $C$. longa. In conclusion the inclusion of Curcuma longa powder at $0.25 \%$ improved feed intake and digestibility in Guinea pigs.

Keywords : Curcuma longa, Cavia porcellus, digestibility, feed intake

\section{Introduction}

Malnutrition affects approximately $20 \%$ of the Cameroonian population [25]. To fight against this scourge, the development of small scale breeding offers an alternative source of proteins as much as it contributes in a global way to the economy of the country through the promotion of employment, exchanges and the preservation of biodiversity [16]. Among the species concerned, caviaculture offers the guarantee of food security for vulnerable populations, especially in rural areas Fokom et al. [12].

Indeed, Guinea pig is a monogastric herbivore whose main interest lies in a high speed of relative growth, lean meat, an inexpensive natural diet, low capital and labor requirements [17]. Its optimal use as a source of protein and income [16], therefore requires an increase in its productivity which necessarily involves improving breeding strategies on the one hand and better rational management methods of production on the other hand.

In fact, poor breeding strategies lead to low productivity (stunting, low fertility, abortions, low birth weights and high mortality due to poor health) [13].

The use of growth promoters (phytobiotics, prebiotics and symbiotics) has been reported to enhance growth performance, prevent pathogens and promote the growth of beneficial microorganisms in the intestinal flora of animals [3]. Among these compounds, phytobiotics have many properties (antioxidant, antimicrobial, improving digestion and stimulating the immune system). 
Curcuma longa is a plant famous for its culinary and medical uses. It contains non-volatile curcuminoids that are the main constituents responsible for its yellow color [8]. It has a very wide variety of pharmacological properties [15]. According to Brahimi and Terrai [9] it contains active ingredients such as tetrahydro-curcuminoids, curcumin, demethoxy-curcumin and bisdemethoxycurcumin which are non-toxic polyphenolic derivatives of curcumin which possess a wide range of biological activities. Other studies have shown that curcumin has toxic effects on both Enterococcus faecalis and Streptococcus intermedius and on Escherichia coli [14].

In addition, Abdel et al [3] also revealed that supplementation of 0.2 and $0.4 \mathrm{~g} / \mathrm{kg}$ of $C$. longa powder in rabbit diet increased weight gain. Basavaraj et al [5] recorded an increased in live weight and broiler weight gain with the use of $C$. longa as feed additive at a level of $0.5 \%$. However, Basavaraj et al. [5] recorded no effect following the inclusion of Curcuma longa rhizome powder at 0; 0.15 and $0.30 \%$ on the biochemical characteristics of rabbit blood and meat. Based on these advantages, C. longa has value in animal husbandry and the existing work shows a lot of disparities depending on the animal species used. It is in this perspective that the present work was aimed to evaluate the effect of $C$. longa on feed intake and digestibility in Guinea pigs.

\section{Material and methods}

\section{Experimental site}

This study was carried out at the Cavia porcellus Unit of the Teaching and Research Farm of the Faculty of Agronomy and Agricultural Sciences of the University of Dschang, Cameroon. Dschang is located in the West region of Cameroon at $05^{\circ} 26^{\prime} \mathrm{N}$ and $10^{\circ} 26^{\prime} \mathrm{E}$. The area experiences a wet season from March to November and a hot dry season for the rest of the year. Maximum ambient temperature is around $21^{\circ} \mathrm{C}$, while an average annual rainfall of $2000 \mathrm{~mm}$ is prevalent.

\section{Plant material}

Curcuma longa was harvested in the district of Santchou (West region of Cameroon), sun dried, then ground into powder using a hammer mill of sieve size $2 \mathrm{~mm}$. The powdered spice was then stored in air-tired polythene bags prior to use in the experimental rations. Sample of the test spice was stored in a refrigerator at a temperature of $4^{\circ} \mathrm{C}$. The phytochemical analyses of Curcuma longa was carried out as described by Talukdar et al. [22] revealed that alkaloids, flavonoids, terpenoids, phenols, steroids and tannins were presents.

\section{Animal material and housing}

A total of forty (40) animals (20 males and 20 females) with an average weight of $452 \pm 75 \mathrm{~g}$ were used and housed in four pens. These pens were made of plywood, measuring $1 \times 0.8 \times 0.6$ $\mathrm{m}$, equipped with light facilities. Each compartment or lodge was equipped with a wooden trough for feed, a concrete water trough and a device for collecting left over feed and feces. The various boxes were fitted with a fine-mesh cover to protect the animals from mice and other predators that could enter the barn. 
Effects of graded levels of Curcuma longa Powder on in vivo digestibility in ...

\section{Animal Experimental Diet}

The animals were distributed into four treatments in a completely randomized design ( $\mathrm{R}_{0 \%}, \mathrm{R}_{0.25}$, $\mathrm{R}_{0.5 \%}$ and $\mathrm{R}_{1 \%}$ C. longa). Each treatment contains 10 Guinea pigs ( 5 males and 5 females). From the basal diet, $\left(\mathrm{R}_{0 \%}\right)$ three experimental rations were formulated by adding $C$. longa powder (Table 1) as follow:

\section{Table 1: Chemical composition $(\mathrm{g} / 100 \mathrm{~g})$ of basal diet}

\begin{tabular}{|c|c|}
\hline Ingredients & Quantity (\%) \\
\hline Maize & 22 \\
\hline Trypsacum laxum & 26 \\
\hline Soybean meal & 4 \\
\hline Cotton cake & 3 \\
\hline Palm kernel cake & 9 \\
\hline Fish meal & 8 \\
\hline Bone meal & 1 \\
\hline Wheat bran & 22 \\
\hline *Premix 10\% & 2 \\
\hline Oyster Shell & 1 \\
\hline Molasses & 2 \\
\hline Total & 100 \\
\hline
\end{tabular}

*Vitamin premix provided per kilogram of diet: vitamin A, $3000000 \mathrm{IU}$, vitamin D3: $600000 \mathrm{IU}$; vitamin E: 4000 mg; vitamin K: 500 mg; vitamin B1: 200 mg; vitamin B2, 1000mg; vitamin B6: 400 mg; vitamin B12: 4 mg; Mn, 80 mg; Fe: 8000 mg; Zn: 10000 mg; Cu,: 2000mg; Methionine: 200000 mg; Lysine: 78000 mg; Se: 20mg

\section{Evaluation of the chemical composition of the rations}

The chemical composition of the rations were performed to determine dry matter, ash, organic matter, crude fibre, crude protein, and crude fat contents, as described by AOAC [1]. It was determined at the Animal Nutrition Laboratory of the Faculty of Agronomy and Agricultural Sciences of the University of Dschang. 


\section{Feed intake and digestibility assessment of rations}

Feeds was served every morning at 8:00 am. The quantity of feed served was registered, and the left over was collected daily and weighed. Feed intake was obtained by subtracting the left over feed from the total quantity of feed served to the animals.

The digestibility test followed a 10-day adaptation period of the animals in digestibility cages and pelleted rations. During this period, the amounts of feed served was adjusted to the estimated consumption of $60 \mathrm{~g} /$ animal / day. Data was collected each morning within a period of seven days. Faeces were collected, weighed and dried at $60^{\circ} \mathrm{C}$ in a ventilated oven. Analysis of dry matter (DM), organic matter (OM), crude protein (CP) and crude fiber (CF) content was carried out according to the method described by AOAC [1]. The apparent digestibility coefficients of dry matter, organic matter, crude proteins and crude fiber were calculated according to the formula described by Roberge and Toutain [19]:

Digestibility $(\%)=[($ nutrient intake $(\mathrm{g})$ - nutrient excreted in faeces $(\mathrm{g}) /$ nutrient intake $(\mathrm{g})] \mathrm{x} 100$

\section{Statistical analysis}

Data on feed intake and nutrient digestibility were subjected to one-way analysis of variance (ANOVA) following the general linear model of statistical package for Social Science (SPSS.21.0) sofware. Polynomial regressions were carried out to determine the relationship between the rate of inclusion of the test spice and the different parameters studies (feed intake and digestibility). Where significant differences existed between treatments, the means were separated by the Waller Duncan test at 5\% significance level [21].

\section{Results}

\section{Phytochemical composition of $C$. Ionga and chemical composition rations}

Phytochemical analysis shows that $C$. longa contains the following bioactive compounds such as alkaloids, flavonoids, phenols, steroids, tannins, terpenoids and saponins (Table 2). 
Effects of graded levels of Curcuma longa Powder on in vivo digestibility in ...

Table 2: Phytochemical composition of C. longa

\begin{tabular}{|l|l|}
\hline Bio-active Constituents Classes & Observations \\
\hline Alcaloïds & + \\
\hline Flavonoïds & + \\
\hline Phénols & + \\
\hline Stéroïds & + \\
\hline Tannins & + \\
\hline Terpenoïds & + \\
\hline Saponins & - \\
\hline
\end{tabular}

$+\mathrm{ve}=$ present $-\mathrm{ve}=\mathrm{absent}$

\section{Effects of the rate of incorporation of Curcuma longa powder on feed intake in Guinea pigs}

The inclusion of Curcuma longa powder in the different diets significantly improved $(p<0.05)$ feed intake in Guinea pigs regardless of the inclusion level (Figure 1). The crude fiber intake by animals fed on $\mathrm{R}_{0.5 \%}$ ration was comparable ( $\mathrm{p}>0.05$ ) to animals fed with $\mathrm{R}_{0.25 \%}$ and $\mathrm{R}_{1} \%$ rations, but significantly higher $(\mathrm{p}<0.05)$ to the control ration $\left(\mathrm{R}_{0} \%\right)$. However, ingestion of crude fiber from the control diet was significantly $(\mathrm{p}<0.05)$ lower compared to the rations containing Curcuma longa. Crude fiber ingested by animals fed on $\mathrm{R}_{0.25 \%}$ and $\mathrm{R}_{1} \%$ rations were comparable ( $\mathrm{p}>0.05$ ) and significantly lower $(\mathrm{p}<0.05)$ than those fed with $\mathrm{R}_{0.5 \%}$ ration.

The regression value $(p<0.05)$ derived $\left(R^{2}=0.94\right.$ for $D M, R^{2}=0.95$ for OM, $R^{2}=0.95$ for $C P$ and $\mathrm{R}^{2}=0.97$ for $\mathrm{CF}$ ) suggest that, the variation of DM, OM, CP and CF are $94 \%, 95 \%, 95 \%$ and $97 \%$ respectively dependent on the rate of inclusion of $C$. longa in the rations. 

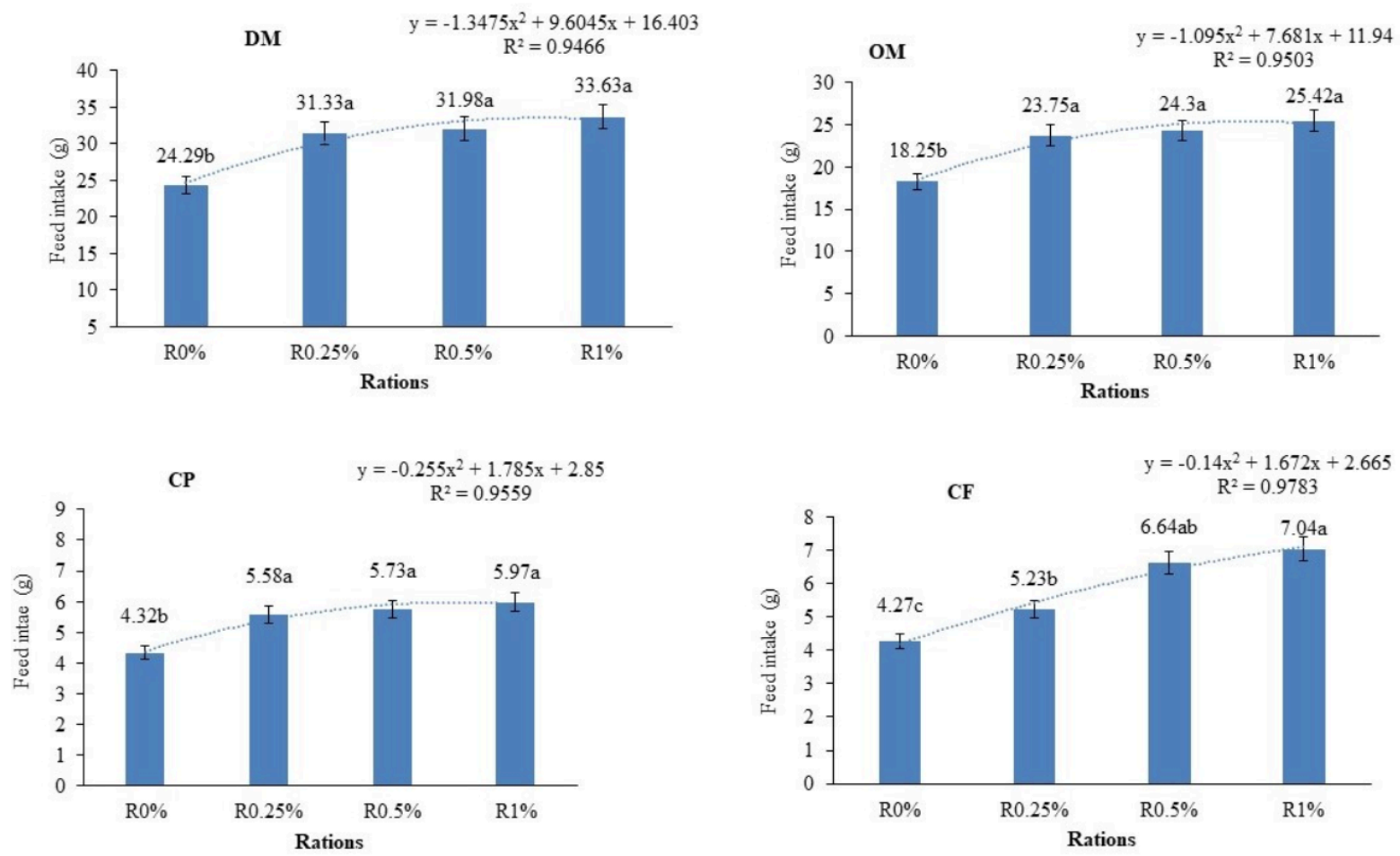

Figure 1: Effect of the level of incorporation of Curcuma longa powder as a feed additive on nutrient intake in Guinea pigs.

$a, b$ : Means on the same row with the same superscripts do not differ significantly ( $p>0.05$ ); R0\%: without C. longa; $R 0.25 \%=R 0 \%+0.25 \%$ C. longa $R 0.5 \%=R 0 \%+0.5 \%$ C. longa $R 1 \%=R 0 \%+1 \%$ C. longa. DM: Dry matter; OM: Organic matter; CP: Crude protein; CF: Crude fiber.

\section{Effect of the rate of incorporation of Curcuma longa powder on nutrient digestibility in Guinea pigs.}

The inclusion of different rates of Curcuma longa powder had significant effects $(p<0.05)$ on the digestibility of dry matter and crude fiber. In addition, crude protein and organic matter were comparable $(p>0.05)$. The best digestibility was observed with the ration containing $0.25 \%$ Curcuma longa.

The polynomial adjustment of the digestibility of nutrients according to the different levels of inclusion of $C$. longa induced a high regression coefficient $\left(\mathrm{R}^{2}=0.87\right.$ for CFD) indicating a strong relation between digestibility and the rate of inclusion $C$. longa in feed. However, the regression value $(\mathrm{p}<0.05)$ derived $\left(\mathrm{R}^{2}=0.68\right.$ for $\mathrm{DMD}, \mathrm{R}^{2}=0.59$ for $\mathrm{OMD}, \mathrm{R}^{2}=0.59$ for CPD) suggest that the variation of $\mathrm{DMD}, \mathrm{OMD}$ and $\mathrm{CPD}$ are moderately related to the level of incorporation of $C$. longa in the ration. 
Effects of graded levels of Curcuma longa Powder on in vivo digestibility in ...
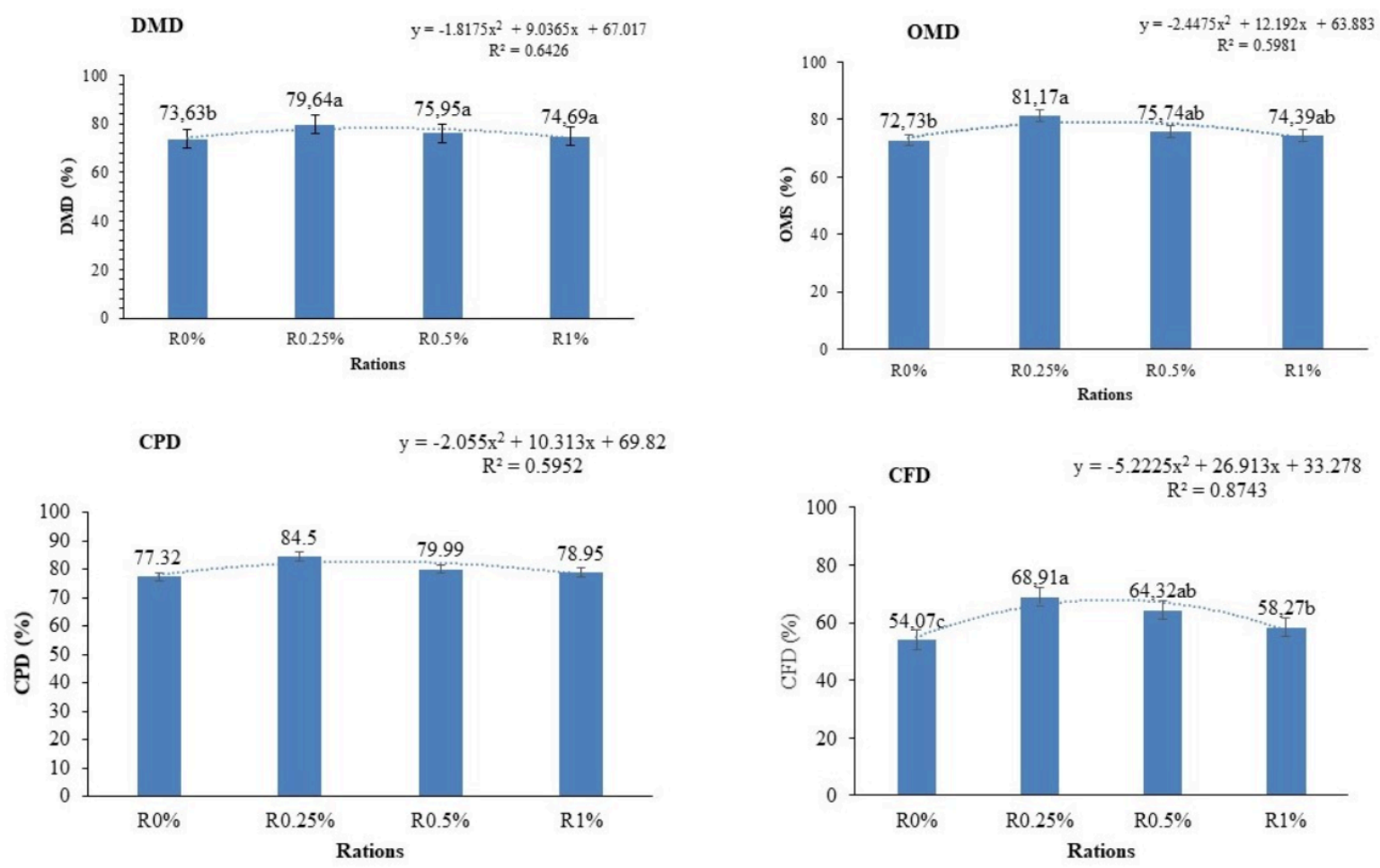

Figure 2: Effect of the level of incorporation of Curcuma longa powder as feed additive on in vivo digestibility of nutrients in Guinea pigs

$\mathrm{a}, \mathrm{b}$ : Means on the same row with the same superscripts do not differ significantly ( $\mathrm{p}>0.05$ ); R0\%: without C. longa; $\mathrm{R} 0.25 \%=\mathrm{R} 0 \%+0.25 \%$ C. longa; $\mathrm{R} 0.5 \%=\mathrm{R} 0 \%+0.5 \%$ C. longa; R1\% = R0\% + 1\% C. longa. DMD: Dry matter digestibility; OMD: Organic matter digestibility; CPD: Crude protein digestibility; CFD: Crude fiber digestibility.

\section{Discussion}

Qualitative phytochemical analysis revealed that $C$. longa contain bioactive compounds such as alkaloids, flavonoids, phenols, steroids, tannins, terpenoids and saponins that can affect feed intake and digestibity of nutriments. Attou and Boukhari [2] also revealed the presence of flavonoids, alkaloids, tannins, phenols and steroids in $C$. longa powder and their in vitro antimicrobien activity.

Feed intake increased with the incorporation of Curcuma longa powder compared to the ration without additive. This increase could be due to the odour and flavour produced by the additive. According to Bertin et al [6], olfactory stimuli have a considerable influence on the feeding preferences and behaviour of animals. This result corroborates that of Vivian et al. [24] who reported a significant increase in feed intake of broilers fed on garlic and ginger powder. However, a decrease in feed intake was observed with $1 \%$ incorporation rate of $C$. longa. This could be due to the presence of alkaloids in the spices which could have induced a bitter taste to the feed. According to Bouvarel et al [8], animals consume less feed with a bitter flavour, followed by salty, sour and sweet.

However, animals fed with $C$. longa powder had a higher digestibility than animals fed with the additive-free ration. This result agrees with those of Abdullahel et al [4] who showed that the inclusion of $C$. longa powder in broilers feed inhibits coliform bacteria, yeasts and moulds present 
in the caecum, thus promoting nutrient absorption. This could also be explained by the effects of curcuminoid which may have favoured the secretion of emulsions at the level of the gall bladder, thus facilitating the digestion of nutrients. Furthermore, the work of Tekeli et al [23] revealed that the incorporation of $2 \%$ Ginger in broilers ration improved digestion of nutrients. The muchappreciated beneficial effects of $C$. longa could be masked by the presence of tannins which have the ability to form complex and reduce the availability of proteins, sugars and many minerals essential for the growth of bacteria in the digestive tract.

This ability to bind to proteins, under certain conditions especially at high doses, anti-nutritional agents that can inhibit enzymes in the digestive tract and reduce the availability of certain dietary proteins to the host [20]. This result is consistent with that of Vivian et al. [24] who reported an increase in digestibility in broilers receiving $50 \mathrm{ml} / \mathrm{L}$ of garlic and ginger infusion through drinking water. In contrast, Nweze et al [18] reported that administration of Tetrapleura tetraptera powder through feed had no significant effect on live weight of broilers. Similarly, Ebile et al [11] reported that, administration of Dichrostachys glomerata powder via feed and drinking water had no significant effect on nutrients utilization (feed conversion ratio) of quails.

The increased digestibility in this study could be due to the presence of active ingredients such as phenols, terpenes and flavonoids present in C. longa, which have antibacterial, anti-inflammatory and antioxidant properties on one hand and, above all, minerals important for metabolic processes that could have favoured the growth of the animals. According to Burt [12], phenolic compounds are capable of crossing the phospholipid bilayer of the bacterial membrane, causing degradation of the membrane, ion leakage and possibly killing the cells. The reduction of pathogenic bacteria, illustrated by the decreased in bacterial load of Escherichia coli and Salmonella in our study, thus maintained the animal in good health, increased the availability of nutrients and thus improved digestibility.

\section{Conclusion and Recommendation}

C. longa powder can be used in Guinea-pig diet as phytobiotic. At moderated levels of inclusion, it improves dietary intake and nutrient digestibility in this species.

\section{Bibliographie}

[1] A.O.A.C. (Association of Official Analytical Chemist), 2000. Official method of analysis. $15^{\text {th }}$ ed. Washington D.C. 10 p.

[2] Attou S. et Boukhari F. 2013. Ethnobotanical and phytochemical survey and evaluation of some biological activities of Curcuma longa Linne. University Saad Dehleb-blida1, Faculty of Natural and Life Sciences, Department of Biology. Dissertation for the Master II degree, defended on 22 $/ 12 / 2013$

[3] Abd EL-Latif, S.A., Toson, M.A., Elwan, H.A.M. et Esraa, S.H. 2019. Effect of Dietary Growth Promoters on Some Physiological Responses of Growing Rabbits. Acta Scientific Medical Sciences, 3, 66-70. https://doi.org/10.31080/ASMS.2019.03.0442.

[4] Abdullahel Kafi, 2017. Effect of Dietary Supplementation of Turmeric (Curcuma longa), Ginger (Zingiber officinale) and their Combination as Feed Additives on Feed Intake, Growth Performance 
Effects of graded levels of Curcuma longa Powder on in vivo digestibility in ...

and Economics of Broiler rabbits. Article. International Journal of Poultry Science, 16(7), $257-265$.

[5] Basavaraj M., Nagabhushana V., Prakash N., Mallikarjunappa S., Appannavar M.M. and Prashanth W. 2017. Effect of dietary supplementation of Pulvis Curcuma Longa on the voluntary feed intake, nutrient digestibility and Growth performance of supplementation of Pulvis Curcuma longa on the voluntary feed intake, nutrient digestibility and Growth performance of Broiler rabbits under summer stress. Veterinary World, 3(8), 369-372.

[6] Bertin A., Calandreau L., Arnould C. and Lévy F., 2012. The developmental stage of chicken embryos modulates the impact of in ovo olfactory stimulation on food preferences. Chemical senses, 37(3), 253-261.

[7] Boufeker S. et Aggoune D.Z., 2018. Isolement et Caractérisation Structurale de Curcuminoides d'Origine Naturelle. Mémoire de Master, Université des Frères Mentouri Constantine, Faculté des Sciences de la Nature et de la Vie. République Algérienne Démocratique et Populaire. 113p.

[8] Bouvarel I., Tesseraud S. and Leterrier C., 2010. Ingestion in broilers: let's not forget the shortterm regulations. INRA Production Animale, 23 (5) : 391- 404.

[9] Brahimi I. et Terrai R., 2018. Evaluation de l'activité anti-oxydante des deux plantes Rosmarinus officinalis et Curcuma longa. Mémoire de Master, Université des Frères Mentouri Constantine, Faculté des Sciences de la Nature et de la Vie. République Algérienne Démocratique et Populaire. 84 p.

[10] Burt S., 2004. Essential oils: their antibacterial properties and potential applications in foods a review. International Journal of Food Microbiology, 94: 223-253.

[11] Ebile Dayan A., Kana J.R., Pimagha M.H.J., Edie Nounamo L.W., Nguefack Djieufo G., Ngouana Tadjong R. and Fonteh A.F. 2018. Effects of Dichrostachys glomerata Feeding Regimes on Growth Performance, Gut Microbiota and Haemato-Biochemical Profile of Japanese Quails. Journal of Animal Research and Nutrition, 3(2): 1-8.

[12] Fokom Wauffo D., Tendonkeng F., Miégoué E., Djoumessi Tobou F. G., Sawa C., Mouchili M., Azangue Jiope G., 2020a. Ingestion and in vivo Digestibility of a Concentrated Granulated Feed Containing Seeds of Moringa oleifera Associated with Pennisetum purpureum in Guinea Pigs Open Journal of Animal Sciences, 2020, 10, https://www.scirp.org/journal/ojas ISSN Online: 2161-7627 ISSN Print: 2161-7597

[13] Fokom Wauffo D., Tendonkeng F., Miégoué E., Sawa C., Djoumessi Tobou F-G., Mouchili M. et Azangue Jiope G., 2020b. Ingestion et digestibilité in vivo d'un aliment composé granulé contenant les graines de Moringa oleifera chez le cochon d'Inde. Livestock Research for Rural Development. Volume 32, Article \#3. Retrieved May 15, 2021, from http://www.lrrd.org/lrrd32/1/ f.tend32003.html.

[14] Haukvik T., Bruzell E. M., Kristensen S. and Hjorth T. H., 2009. Photokilling of bacteria by curcumin in different aqueous preparations. Studies on curcumin and curcuminoids.

[15] Kamran A. et Sadia S., 2017. A comprehensive review on Curcuma longa Linn.: Phytochemical, pharmacological, and molecular study. International Journal of Green Pharmacy; Oct-Dec 2017 (Suppl); 11 (4) S685. 
[16] Miégoué E., Nguedia G., Tendonkeng F., Djoumessi Tobou F. G., Ntsafack P., Tatsinkou S.A., Fossi J. et Pamo T.E., 2019. Zootechnical performance of the guinea pig (Cavia porcellus L.) subjected to different levels of spirulina (Arthropsira platensis). Journal of Applied Biosciences 140 : 14316 - 14326, ISSN 1997-5902.

[17] Nguedia G., Miégoué E., Tendonkeng F., Sawa C., Ntsafack P., Djoumessi Tobou F. G., Tatsinkou S. A.et Pamo Tedonkeng E. 2019. Performances de production du cobaye (Cavia porcellus) en fonction du niveau de spiruline de la ration dans la région de l'Ouest-Cameroun. Int. J. Biol. Chem. Sci. 13(3): 1245-1260.

[18] Nweze B.O., Nwankwegu A.E. and Ekwe O.O. 2011. The performance of the broilers chickens on African porridge fruit (Tetrapleura tetraptera) pod under different feeding regimes. Asian Journal of Poultry Science, 5(4), 144-149.

[19] Roberge G. et Toutain B. 1999. Choix des Cultures fourragères tropicales. In: Roberge, G. et Toutain, B. (eds). Cultures fourragères tropicales. CIRAD, Montpellier France. Pp 321-357.

[20] Serrano J., Puupponen-Pimia R., Dauer A., Aura A.M. and Saura-Calixto F., 2009. Tannins: current knowledge of food sources, intake, bioavailability and biological effects. Molecular Nutrition and Food Research, 53: 310-329.

[21] Steel R.G. et Torrie J.H., 1980. Principles and procedures of statistics. New York, McGraw Hill Book C. 633p. Pharmazie 64(10):666-73, DOI: 10.1691/ph.2009.0000.

[22] Talukdar, A.D., Choudhary, M.D., Chakraborty, M. and Dutta, B.K. 2010. Phytochemical Screening and TLC Profiling of Plant Extracts Cyathea gigantea (Wall. Ex. Hook.) Haltt and Cyathea brunoniana Wall. Ex. Hook. (Cl. \& Bak.). Journal of Science and Technology: Biological and Environmental Sciences, 5, 70-74.

[23] Tekeli A., Kutlu H.R. \& Celik L., 2011, Effect of Z. officinale and propalis extracts on the performance, carcass and some blood parameters. Current Research in Poultry Science Volume 1 (1): 12-23, 2011.

[24] Vivian O., Harriet M.N.F., Solomon O.O. et Joesph O.U. 2015. Evaluation of Growth Performance, Haematological and Serum Biochemical Response of Broiler Chickens to Aqueous Extract of Ginger and Garlic. Journal of Agricultural Science, 7: 167-173.

[25] World Food Programme 2017, Via C. G. Viola 68 Parco dei Medici - 00148 Rome, Italy.

PDF généré automatiquement le 2023-04-26 13:47:55

Url de l'article : https://popups.uliege.be/2295-8010/index.php?id=1847 